\title{
Competency Level of Employees at Automobiles Industry Chennai
}

\section{R. Devi}

\begin{abstract}
It is a fundamental thought that chooses the achievement of an association. Abilities are the internal contraptions for convincing agents, planning systems and shapes and coordinating the business towards shared destinations that empower the associations to grow its value. Abilities give an ordinary language and methodology that can facilitate all the genuine HR limits and organizations like Recruitment, Training, execution the officials, Remuneration, Performance assessment, Career and movement orchestrating and fused Human resource the administrators structure. The examination attempts to find the competency level of delegates at vehicles adventures.
\end{abstract}

Keywords: Personal Ability, Competency Level of Employee, Relationship Ability.

\section{INTRODUCTION}

Over the span of late years, human resource and definitive improvement specialists have created a lot of energy for the possibility of abilities as a key part and extent of human execution. Abilities are transforming into an a significant part of the time used and elucidated vehicle for various leveled applications. Doling out compensation assessments and levels to explicit occupations and employments. Capacities fuse the social occasion of accomplishment factors key for achieving huge results in a specific movement or work in a particular affiliation. Accomplishment segments are blends of data, capacities, and characteristics (even more by and large called "KSA's") that are delineated similar to express rehearses, and are appeared by dominating performers in those jobs or maintain sources of income. Properties include: singular traits, attributes, manners of thinking, characteristics or points of view that impact an individual's lead.

\section{REVIEW OF LITERATURE}

Boverie, P., Grassberger, R., and Law, V. (2013) in his investigation he found that the present associations seek top ability in a worldwide commercial center. Representatives look for work that is fascinating and important, where they can be locked in and constantly learning. While much is expounded on representative commitment, pioneers need a model for organizing work environments where workers can be enthusiastic about their work and where there are open doors for workers to learn and develop.

Revised Manuscript Received on December 05, 2019.

* Correspondence Author

Dr. R. Devi*, Assistant Professor \& Head, Department of Business Administration, KCS Kasi Nadar College of Arts \& Science, Chennai, India. E-mail: prof.devi001@gmail.com
Sengupta, A., Venkatesh, D. N., and K. Sinha, A. (2013). The purposes of the article are to not simply study existing competency models and offer an extensive execution associated competency model towards proceeding with high ground, yet what's more endorse the proposed model in an Indian material affiliation. The article operationalises the articulation "competency" and hopes to develop a broad execution associated competency model in the wake of dismembering the present models concerning advantage; and the model has been affirmed precisely in an Indian material association using data envelopment assessment (DEA), cross-capability DEA, and rank solicitation centroid (ROC) techniques. It reveals that the broad execution associated competency model spotlights on competency recognizing evidence, competency scoring and changing competency to other key HR works in a three-organize effective methodology which will thusly assist the relationship with supporting in the test. It has furthermore been shown how using DEA, cross-adequacy DEA and ROC, an affiliation can change particular displays and their capacities to the extent capability. In case the amount of abilities gets extended, DEA can't be used. This can be associated with industry for dynamically capable and effective execution estimation gadget. The paper enables relationship to deliberately manage their agent capacities to ensure tip top level and high ground.

\section{OBJECTIVES OF THE STUDY}

- To identify the competency of the employees in Automobiles industry, Chennai.

- To identify the job competency in term of personal ability and relationship ability required for employee to perform their job efficiently \& effectively.

- To study the current competency level of employee.

- To study the competency of the employees with respect to KSA (Knowledge, skill and attitude).

- To create awareness among the employees regarding Competency level at automobiles industry, Chennai.

\section{NEED FOR THE STUDY}

- To facilitate building the skill inventory leading to optimum utilization of man power and hence increase in productivity

- To recognize the competency mapping among the representatives in the association. 


\section{Competency Level of Employees at Automobiles Industry Chennai}

- To improve the competency of the worker and furthermore to upgrade the competency of the representative for better efficiency in the association.

- To make attention to the competency mapping among the representatives in Automobiles industry, Chennai.

\section{SCOPE OF THE STUDY}

The competency mapping is a unique competitive advantage for the each and every organization, in the present context every organization drive forwards competency based activity, like competency based recruitment, employee training, employee retention, and employee development. The research under gone study to know the competency module and effective understand of executive level employee in Automobiles industry, Chennai. Upcoming researcher are studying the competency model to develop the efficiency of the shop floor workers and top management which will in turn increase the productivity and growth of the organization.

\section{LIMITATIONS OF THE STUDY}

- Since the investigation is led in a specific organization, the consequences of this examination can't be summed up to other organization or industry.

- The study thoroughly relies on the data given by the respondent, abstract inclination isn't wiped out.

- Some workers are not keen on uncovering their actual aptitudes/capability, so there is an opportunity of getting false data.

- Due to need time, Sample size is little and inside and out examination isn't finished.

\section{SAMPLE DESIGN}

Sample unit: The sample unit of the study is employee for each level in TVS Sundaram motors Ltd Poonamalle and Wheels India Ltd Padi, Chennai.

Sample Size: The sample size was confined to the 80 respondents for the study.

Type of sampling: Systematic Random Sample - A population is divided into group called strata and a simple is randomly selected from each stratum. In this study the researcher took samples from each department like Engineering, Finance, HR, Production and Material management, IT, SAP and R\&D.

\section{DATA COLLECTION METHOD}

Research Instrument: Structured questionnaire.

Methodology: Personnel Interviews

\section{DATA ANALYSIS AND INTERPRETATION}

The data was collected from 80 employees based on a questionnaire prepared for this purpose. Personal interview also helped to collect data as well as to get a feel of how things work in the organization. The questionnaire was so Design that the data collected can be analyzed and inference can be drawn.

Table - 1: Age classification of the respondents

\begin{tabular}{|c|c|c|}
\hline Age (In Years) & Frequency & Percentage \\
\hline $20-30$ & 48 & 60.0 \\
\hline $31-45$ & 20 & 25.0 \\
\hline Above 46 & 12 & 15.0 \\
\hline Total & 80 & 100 \\
\hline
\end{tabular}

From the above table it is clear that $60 \%$ of the employees are belonging to 20-30 age group, $25 \%$ employees are belongs to $31-45$ age group and $15 \%$ employee are belongs to above 46 years age group.

Table - 2: Classification based on Qualification of the respondents

\begin{tabular}{|c|c|c|}
\hline Qualification & Frequency & Percentage \\
\hline ITI & 10 & 12.5 \\
\hline Diploma & 18 & 22.5 \\
\hline Graduate & 42 & 52.5 \\
\hline Post Graduate & 10 & 12.5 \\
\hline Total & 80 & 100 \\
\hline
\end{tabular}

From the above table $52.5 \%$ of the employees are Graduates, $22.5 \%$ of the employees are Diploma holders, $12.5 \%$ of the employees are Post graduates and $12.5 \%$ of the employees are ITI holders.

Table -3: Correlation between stress tolerance and emotional resilience of employees

\begin{tabular}{|c|c|c|c|c|c|}
\hline Factors & Expert & $\begin{array}{l}\text { More } \\
\text { Capable }\end{array}$ & Capable & Learner & Beginner \\
\hline $\begin{array}{l}\text { Stress } \\
\text { Tolerance } \\
\text { (X) }\end{array}$ & 22 & 28 & 21 & 6 & 0 \\
\hline $\begin{array}{l}\text { Emotional } \\
\text { Resilience } \\
\text { (Y) }\end{array}$ & 11 & 26 & 20 & 13 & 7 \\
\hline \multicolumn{6}{|c|}{$r_{X Y}=\frac{\sqrt{\sum(X-\bar{X})^{2} \sum(Y-\bar{Y})^{2}}}{\sqrt{\sum(X)}}$} \\
\hline & & \multicolumn{2}{|c|}{$\begin{array}{l}\text { Stress Tolerance } \\
\text { (X) }\end{array}$} & \multicolumn{2}{|c|}{$\begin{array}{l}\text { Emotional Resilience } \\
\text { (Y) }\end{array}$} \\
\hline \multicolumn{2}{|c|}{ Stress Tolerance (X) } & \multicolumn{2}{|r|}{1} & & \\
\hline \multicolumn{2}{|c|}{$\begin{array}{l}\text { Emotional Resilience } \\
(\mathrm{Y})\end{array}$} & \multicolumn{2}{|c|}{$0.788^{* *}$} & \multicolumn{2}{|c|}{1} \\
\hline \multicolumn{6}{|c|}{ ** 5\% Level of Significan } \\
\hline
\end{tabular}

There is a very high degree of positive correlation between the Stress Tolerance and Emotional Resilience.

Published By: 


\section{FINDINGS}

- $90 \%$ of the employees are Male and $10 \%$ of the employees are Female.

- $35 \%$ of the employees are married and $65 \%$ of the employees are unmarried.

- $\quad 52.5 \%$ of the employees are Graduate and $12.5 \%$ of the employees are Postgraduate $22.5 \%$ of the employees are Diploma holders and $12.5 \%$ of the employees are ITI holders.

- $37.5 \%$ of the employees are belong to Production/Material Management Department, 27.5\% of the employees are belongs to Engineering Department level, $20 \%$ of the employees are belongs to IT/SAP/R\&D Department, and $15 \%$ of the employees are belongs to Finance/HR Department.

- $28 \%$ of the employees are above 1 - 3 years of experience, $23 \%$ of the Executive are belongs to $3-5$ years of experience. And 26\% of employees are belongs $5-7$ years of experience. lastly $14 \%$ of employees are belongs to $7-10$ years of experience and $10 \%$ of employees are above years of experience.

- $\quad 42.5 \%$ of respondents are getting the pay Rs, 10,000 Rs, 20,000. $27.5 \%$ of respondents are getting a pay Rs, 5000 - Rs, $10,000.17 .5 \%$ of respondents are getting the pay above Rs, 20,000. $12.5 \%$ of the respondents are getting the pay underneath Rs, 5000 .

- It's found that, Competency like Responsibility, Target orientation, Discipline, Problem Solving, Self knowledge, Self Starting and proactive, Stress tolerance should be in Expert level for an Engineering executive. The Evaluation, problem solving, cross functional perspective, Creative thinking should be in more than capable for an engineering executive. Motivation, Decision ability should be in Capable level, for an engineering Executive.

\section{CONCLUSION}

Based on the analysis conducted at Automobile industry based companies, its evident that the worker ability and skills have the best potential to assist the corporate to realize its business objectives. The corporate has to work on planning a correct structure to live every individual's competence and facilitate them to grow one by one with the organization this cannot solely inspire then however conjointly retain them at intervals the organization as they feel extremely happy.

\section{REFERENCES}

1. Boverie, P., Grassberger, R., \& Law, V. (2013). Leading individual development and organizational change around learning, meaning, and nurturing environment. Advances in Developing Human Resources, 15(4), 382-400.

2. Cesyniene, R. (2005). The most recent trends and emerging values in human resource management: comparative analysis. Inžineriné ekonomika, (4), 50-55.

3. Day, M. T. (1998). Transformational discourse: ideologies of organizational change in the academic library and information science literature.
4. Gardner, W. L., \& Schermerhorn, J. R. (2004). Unleashing individual potential. Organizational dynamics, 3(33), 270-281.

5. Laakso-Manninen, R., \& Viitala, R. (2007). Competence management and human resource development: a theoretical framework for understanding the practices of modern Finnish organisations. Haaga-Helia University of Applied Sciences.

6. Sengupta, A., Venkatesh, D. N., \& K. Sinha, A. (2013). Developing performance-linked competency model: a tool for competitive advantage. International Journal of Organizational Analysis, 21(4), 504-527.

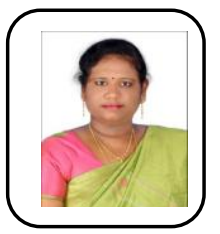

\section{AUTHOR PROFILE}

Dr, R.Devi, M.Com(C.S.), M.Phil., M.B.A., M.Sc (Psy).,Ph.D., SET., is working as Head of the Department of Business Administration, K.C.S Kasi Nadar College of Arts \& Science, Chennai. She had 11 years experience in the teaching field. She has presented more than 25 papers in National and International Conferences and also published research articles in both National and International Journals. 